\title{
Emotion Regulation in Teachers for Students with Special Needs in Inclusive Islamic Elementary School: An Interpretative Phenomenological Analysis
}

\author{
Lucky Ade Sessiani ${ }^{1}$, Fatah Syukur ${ }^{2}$ \\ Universitas Islam Negeri Walisongo Semarang, Indonesia \\ \{lucky_sessiani@walisongo.ac.id', fsyukur@walisongo.ac.id²\}
}

\begin{abstract}
Being a teacher means performing an emotional endeavor. Especially for teachers working with special needs students. This research aims to explore the emotion regulation strategies used by teachers while working with special needs students. A total of 5 individuals, special needs teachers in inclusive Islamic elementary school (Madrasah Ibtidaiyah) participated in the study. Using interpretative phenomenological analysis (IPA), the emerging themes from teacher's experiences indicate that awareness and belief in emotional experiences encouraged teachers to apply emotion regulation strategies. As emotion regulation being implemented continuously, teacher's efficacy and well-being will also be developed during the process. These findings provide deeper understanding about emotion regulation as a skill that enriches teacher's emotional competencies. Thus, it needs to be developed, especially for teachers in special education or inclusive schools, not only to support children behavior and classroom management, but also teacher's well-being and mental health.
\end{abstract}

Keywords: Emotion Regulation; Well-Being; Inclusive School Teachers; Special Needs Teachers

\section{Introduction}

Teachers, like other individuals, experienced emotions in vary. Some research indicate that teaching is an emotional labor, it requires high emotional effort and has high potential risk in escalating stress level [1]-[4]. Special needs teacher in inclusive schools are dealing with more stressors. They are working with special needs students encompassed with cognitive, social, emotional, and/or behavioral disabilities and face a real challenges regarding preparedness in personal and professional terms. As suggested by Taylor \& Ringlaben, at first, teachers in inclusive schools need to feel prepared and have more positive attitudes toward inclusion system itself, in order to meet student's individual needs and have more positive approach in teaching [5].

Nevertheless, inclusive education system implementation in Islamic school institution under the Ministry of Religious Affair of Indonesia, well-known as Madrasah, still needs to be developed. Islamic inclusive schools faces a real challenges, on how to merge between the limited availability of facilities and resources, and the need for inclusive education. Previous research on Islamic schools are mostly focused on the system implementation and evaluation [6], [7], while the research on inclusive school teacher focused on their perception toward inclusive education system and how they cope with their personal or institution readiness to 
perform inclusive education practice [5], [8], [9]. The current study aims to focus on the experience of special needs teachers in inclusive Islamic elementary school (Madrasah Ibtidaiyah), especially on how they manage their emotional experience and apply emotion regulation strategies while teaching students with various special needs characterisics.

How teachers perform emotion regulation strategies has attracted many researchers in educational psychology and then provide remarkable findings that teacher's emotion regulation effect classroom management [10], improve teaching effectiveness [1], [11], maintain teacher's ideal professional image [2], [11], and enhance the sense of well-being [3], [4], [12]. A number of research has shown that practicing emotion regulation skill may result on the improvement of the social and emotional competence [4], stress management [3], [4], [13], resilience [13] [14], and emotional well-being [4], [13], [15]. Martin E. P. Seligman, the founding father of positive psychology, defines well-being as a broad construct comprised by some indicators: positive emotions, engagement, meaning, positive relationship, and accomplishment. Furthermore, despite living to seek for life satisfaction, he consider people are in need to flourish: increasing positive emotions, engagement, meaning, positive relationship, and accomplishment [16]. Suggested by Jennings, et.al, training social and emotional competence on teachers may result in long term positive effects: improving emotion regulation skill and enhancing the sense of well-being. However, among all of these research regarding teacher's emotion regulation and well-being, there are still few evidences on how it manifests in the living experience of special need teachers in inclusive school. Thus, this current study aims to provide answers on how does special need teacher's experience in performing emotion regulation strategies in classroom, and how it impacts their emotional well-being?

Emotion regulation defined as processes by which individuals influence which emotions they have, when they have them, and how they experience and express these emotions. Emotion regulation may be automatic or controlled, conscious or unconscious, and may effects some of the emotion generative process [17]. Gross classified emotion regulation strategies into five major process: (1) situation selection, which involve process avoiding circumstances which cause negative affect or seeking those generating positive affect; (2) situation modification, which aims to alter the situation so that emotions are encouraged; (3). attention deployment, a process to redirect attention to improve emotions; (4) cognitive change (reframing or reappraisal), which involves re-evaluating the personal meaning of a situation; and (5) response modification, a process when person's directly show physical, psychological or behavioral reaction to respond situations provoking negative affect [12], [15], [17].

Moreover, Sutton, et.al. conceptualize emotion regulation strategies based on the process model previously developed by Gross [15], [17], [10]. The work of Sutton found that teachers used a variety of preventative and responsive emotional regulation strategies to help them regulate their emotions in classroom [11]. Sutton's preventative strategies consist modifying situation, attention deployment and cognitive change, usually apply to prevent the development of negative emotions; while responsive strategies often used when in the middle of emotional situation, consisting behavioral and emotional strategies [10], [11] as shown in Tabel 1 .

\begin{tabular}{|c|c|c|}
\hline Strategies & When it is Used & Examples of Strategies \\
\hline \multicolumn{3}{|l|}{ Preventative strategies } \\
\hline \multirow[t]{2}{*}{ Modifying situations } & Before class & $\begin{array}{l}\text { Prepare or revise lessons, tell students } \\
\text { not in a well condition. }\end{array}$ \\
\hline & At the emotion cue & Give assignment, ask question, give instruction, \\
\hline
\end{tabular}




\begin{tabular}{|c|c|c|}
\hline Strategies & When it is Used & Examples of Strategies \\
\hline Attention deployment & Before class & $\begin{array}{l}\text { or make a joke. } \\
\text { Think positive thoughts, pause from activities, } \\
\text { take a sit, talk to friends, or self-talk. } \\
\text { Divert attention, ignore }\end{array}$ \\
\hline Cognitive change & $\begin{array}{l}\text { At the emotion cue } \\
\text { At the emotion cue }\end{array}$ & - \\
\hline $\begin{array}{l}\text { Responsive strategies } \\
\text { Behavioral strategies }\end{array}$ & At the emotion cue & $\begin{array}{l}\text { Withdraw physically, take a deep breath, } \\
\text { quiet, facial expression. } \\
\text { Go to a quiet place, get some exercise. }\end{array}$ \\
\hline Cognitive strategies & $\begin{array}{l}\text { After class } \\
\text { At the emotion cue } \\
\text { After class }\end{array}$ & $\begin{array}{l}\text { Reflect, think positive, visualize. } \\
\text { Talk to others, do hobbies, learn/read. }\end{array}$ \\
\hline
\end{tabular}

Based on the previous study by Sutton, Sutton, et.al, and Hosotani \& Imai Matsumura explained earlier, the conceptual model was constructed and described as shown in Figure 1 [1], [10], [11].

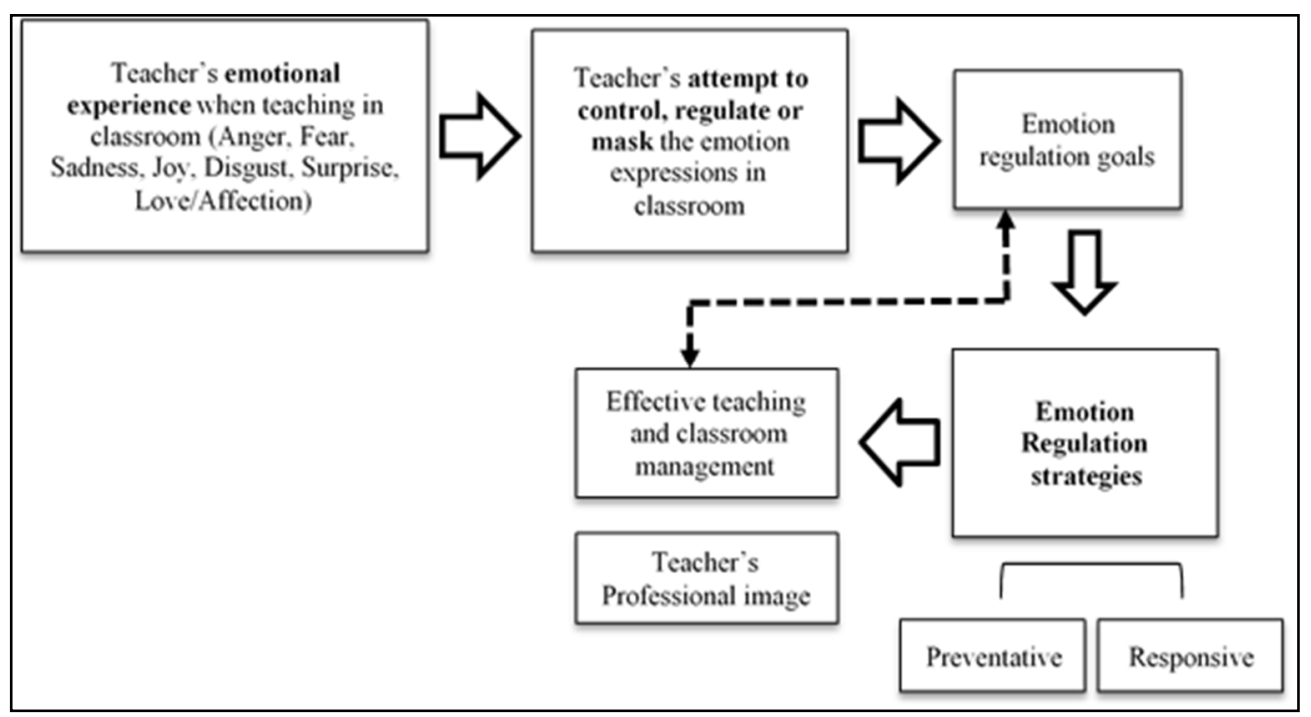

Fig. 1. Conceptual Model of Teacher's Emotion Regulation

\section{Methods}

\subsection{Participants}

A total of 5 participants were selected purposively, they are all worked in the same inclusive Islamic elementary school (Madrasah Ibtidaiyah) located in rural area in Semarang regency. All participants are teachers for special need students, working to assist primary classroom teacher and focus to handle special need students in a inclusive school using pullout system. They treat special need students in classroom by groups as well as in the stimulation/therapy room by individual. The characteristics of the participants described in the 
table below. All participant names in the paper have been changed to initials to safeguard confidentiality.

Table 2. Characteristics of Participants

\begin{tabular}{|c|c|c|c|c|c|}
\hline Characteristics & $\begin{array}{c}\text { P1 } \\
\text { (MS) }\end{array}$ & $\begin{array}{c}\text { P2 } \\
\text { (IK) }\end{array}$ & $\begin{array}{c}\text { P3 } \\
\text { (MR) }\end{array}$ & $\begin{array}{c}\text { P4 } \\
\text { (NL) }\end{array}$ & $\begin{array}{c}\text { P5 } \\
\text { (FF) }\end{array}$ \\
\hline Gender & Woman & Woman & Man & Woman & Man \\
\hline Age & 36 у.о. & 27 у.о. & 27 y.o. & 25 у.о. & 23 у.о. \\
\hline Position & $\begin{array}{l}\text { Special need } \\
\text { teacher }\end{array}$ & $\begin{array}{l}\text { Special need } \\
\text { teacher }\end{array}$ & $\begin{array}{l}\text { Special need } \\
\text { teacher }\end{array}$ & $\begin{array}{l}\text { Special need } \\
\text { teacher }\end{array}$ & $\begin{array}{l}\text { Special need } \\
\text { teacher }\end{array}$ \\
\hline Working period & 5 years & 4.5 years & 8 years & 3 years & 1.5 years \\
\hline \multirow{3}{*}{$\begin{array}{l}\text { Educational } \\
\text { background }\end{array}$} & Bachelor of & Master of & Bachelor of & Bachelor of & Bachelor of \\
\hline & Islamic & Islamic & Islamic & Islamic & Physical and \\
\hline & Education & $\begin{array}{l}\text { Education } \\
\text { Management }\end{array}$ & Education & Counseling & Sport Education \\
\hline
\end{tabular}

\subsection{Data Collection}

In-depth interviews with all participants was conducted in this research, using semistructured interviews applying prompting and probing techniques suggested by La Kahija [18]. Interview guidelines using open-ended questions and probes to explore teacher's emotional experiences and the implementation of emotion regulation strategies, modified from Hosotani \& Imai-Matsumura, Sutton, and Sutton, et.al [1], [10], [11].

\subsection{Interpretative Phenomenological Analysis}

Interpretative Phenomenological Analysis (IPA) is a method in qualitative research aims to explore meanings of particular experiences. It stands above three pillars, namely (1) phenomenology (philosophy that explicitly emphasizes the importance of investigating lived experience that relies on "epoche", a mental state of alertness and attentiveness); (2) hermeneutics (interpretation that relies on the understanding of each participant's statement by maintaining the interconnectivity with the whole transcripts); and (3) idiographic (study of humans in their uniqueness) [18], [19]. IPA approach is best suited to studies that aim to explore participants' experiences in their interactions with the environment. This correlates to the purpose of this study which is to explore a detailed conceptualization of the lived experience of teacher's emotions. Emotions, as a form of lived experience, need a holistic yet idiographic approach in order to be interpreted clearly representing the "world" of a person. IPA acknowledges that it is not possible to access an individual's life world directly because there is no clear and unmediated window into that life. Investigating how events and objects are experienced and given meaning requires interpretative activity on the part of the researcher. This process described as a dual process in which 'the participants are trying to make sense of their world, while the researcher is trying to make sense of how the participants trying to make sense of their world' [20].

This study comprised the six steps of data analysis presented by Smith, Flowers, \& Larkin and La Kahija, namely: (1) Reading and rereading: process to produce verbatim and transcript, read and reread them thoroughly to interpret and explore participants' experiences; (2) Initial noting: adding initial notes and codes in the transcript; (3) Developing emergent themes: based on the initial notes, comparing and contrasting the patterns across cases and connections between notes; (4) Constructing superordinate themes: clustering the connected emergent themes; (5) Searching for connection among cases: compared themes of each transcript with 
those of other cases; and (6) Structuring all superordinate themes: organize all themes to connect participant to particular themes emerged [18], [19].

\section{Results and Discussion}

Using interpretative phenomenological analysis (IPA), five main themes emerged from participant's personal statements and experiences: (1) emotional experiences; (2) beliefs about emotion regulation; (3) emotion regulation strategies; (4) emotion regulation efficacy; and (5) emotional well-being. The findings and discussion explained in subtitles as follows. Quotes from teachers presented in codes (participant number as shown in Table 2, the number of line where the quotes located in the transcript).

\subsection{Teacher's Emotional Experience}

Being a teacher required a complex social interaction toward students, parents, colleagues, or principals. Interaction may act as emotional stimuli and produce emotional experience in the form of positive or negative responses. Hosotani \& Imai-Matsumura's study identified two types of emotional experiences, the ones caused by teacher's personal problems and internal process (self-elicited) and the ones caused students (children-elicited) [1].

Participants describe their emotional experiences in 8 different forms, namely anger, fear, sadness, joy, disgust, surprise, touched, and love/affection. Result analysis shows 3 out of 8 emotional experience confirmed by all participants $(n=5)$, that is anger, joy, and love/affection. Teacher IK describes her anger experiences caused by children's disability to follow instructions and perform a dangerous action:

For example, when I explain how to add number, 1 plus 1 , and the student is still distracted... sometimes I felt like I'm going mad. Also when a child gets tantrum... Once, there was a (special needs) student skipped class and jumped into the river because he really loves water. He refused going back to the class, he just enjoyed playing in the water. As he was having an intellectual disability, he was difficult to understand a situation, he might even don't understand if I am angry $(\mathrm{P} 2, l .30)$.

On the other hand, teacher MS reported having self-elicited anger experience which caused her to feel that student's failure to understand and lack academic performance were her fault.

...there are times when I felt angry at myself, questioned why it has to be so difficult, I mean why, when I have tried to teach a student, I want him to succeed, I have carefully guide him step by step, I have done my best to guide him. Why did I do wrong? How could I not try harder to make him faster to learn and obey... $(\mathrm{P} 1, l .25)$.

As well as anger, there are some variations of joy experience. According to Hosotani \& Imai-Matsumura, variations of joy experience comprises children-elicited joy, pleasant daily interactions, empathetic joy, and successful teaching. Teacher MR described how he felt empathetic joy, he felt happy just to see a student expressing happiness.

When a special needs student is showing happy face, for example, after getting reward from performing well in class, just to watch how she express her happiness, it makes me feel happy too (P3, l.27). 


\subsection{Teacher's Beliefs about Emotion Regulation}

Through describing emotional experiences, teacher's may entering the early stage of emotional awareness which initiates the development of beliefs about emotion regulation. As teachers aware of their emotion, the cognitive process lead them to access information regarding the goals, why they need to perform emotion regulation. Once they understand the benefit, emotion regulation will be conducted as a response toward particular situations (antecedents) [10], [11]. As reported by teacher NL, she described how she developed awareness and cognitive process until she realized that emotion regulation is the only way to control either herself or learning situation.

I was handling a student diagnosed with autism, he also indicated intellectual disability and behavior problems. I was asking him about the second hijaiyah letter, he remained silent. I asked him over and over again, and still not responding. I was thinking that it wasn't his fault, I was wrong in making questions, he did not understand. But I am running out of strategies, so I raised my voice, somehow I lost control of my language, and he became irritated... He hit me every time he thought that I am mad at him. I try not to be angry when he hits, since it was his way to express how he feels. So I have to control my emotion, or otherwise he will try to resist. I will try to be patient and make him enjoyed the learning situation with toys or telling jokes and laughing. I need to always found a way to make situation conducive for learning by controlling my expression $(\mathrm{P} 4, l .120)$.

\subsection{Teacher's Emotion Regulation Strategies}

Once teacher beliefs that emotion regulation is necessary, they will implement the strategies regarding the timing and purpose. Preventative strategies are used to prevent negative emotions from becoming fully developed, while responsive strategies are used respond to emotions during an episode [10], [11]. As shown in Table 1, attention deployment and cognitive change are preventative strategies performed to control the situation before it gets ugly, especially when teacher is having a bad day. Teacher IK said that she tried to think positively, it implies that she is performing attention deployment strategy.

I am using positive words... eventually I feel less-irritated... what bothers me back home, I can manage, by thinking of positive words (P2, l.240).

Meanwhile, teacher MR and NL found it more effective to perform cognitive change strategy by reminding themselves and trying to change the way they think about a situation.

I am trying, although not always succeed, but I try to sort out problems...some problems related to Madrasah, I may think about it further, but some problems are not related, I have to keep them aside (P3, l.174).

Even though I have problems, I am thinking like "wait a minute, one at a time please..." I have to arrange my mind set. I have to prepare, bringing up positive moods when I'm with children, the other things can wait (P4, l.213). 
Teachers need to change strategy when it comes to critical emotional episodes, it is when teacher already fully experienced certain emotions. Teacher MS and FF explained how they applied behavioral strategies as a response toward emotional situation.

When I am angry, and student misbehaves, I just left him with the classroom teacher. I just left him for a while (P1, l.288).

...I gave him a warning, I raised my voice. Sometimes when I got overwhelmed, I just sat beside him, holding his hand and give him a shoulder message. I hold his hand gently while he was writing, so he stayed beside me (P5, l.109).

\subsection{Teacher's Emotion Regulation Efficacy}

As teachers implemented various emotion regulation strategies, they begin to evaluate and developing a sense of efficacy, or a self-confidence to maintain their emotion regulation strategies. The indicator of teacher's efficacy is when they are confidence about their ability to focus on communicating positive emotions and reducing the effect of negative emotions (like anger or stress) while dealing with students [10]. Teacher NL and FF expressed how they become encouraged to control their anger, in order to prevent a potential long term negative effect on children.

I was afraid if I lose control and often gets angry, students will avoid me... and difficult to control, since they thought that their teacher is easy to get angry (P4, l.263).

If I get angry all the time, I will create fear... As I raised my voice, for example, all I can see is fear... It might hurts them and may impact them for a long time (P5, l.121).

\subsection{Teacher's Well Being}

Teacher's appraisal about how emotion regulation create a positive impact on effective teaching and directing student's behavior may result in the feeling of gratitude and selfconfidence. It established the sense of well-being. As previous findings suggested, factors related to teacher's well-being are the ability to perform coping behavior resulted in lower stress level [3], [15], the skill to remain focus and mindful [4], and becoming resilient [13], [14]. Teacher IK felt that the application of emotion regulation strategies allowed her to learn new skills control emotions and gain more focus in maintaining teacher-student relationship.

...positive words, other than making me feel better, it is also can be used to make children listen. (Emotion regulation) make me able to show positive expression, although I am feeling bothered. Applying (emotion regulation) to children can create a better chemistry ( $\mathrm{P} 2, l .113)$.

Teacher NL described her feeling of gratitude and deep spiritual meaning as a result of her effort on performing emotion regulation when teaching children with special needs.

I try my best to keep my patience... (P4, l.155). Allah will not test beyond our capacity, so if Allah said I can, I should believe so.. I always try to enjoy my days with the students, as I watched them grow, the more grateful I am.. I believe there are more blessings... (P4, l.184). 
Summarized the results and discussion, an empirical model was constructed by connecting the themes to create deeper understanding on teacher's emotion regulation and well-being, as shown in Figure 2.

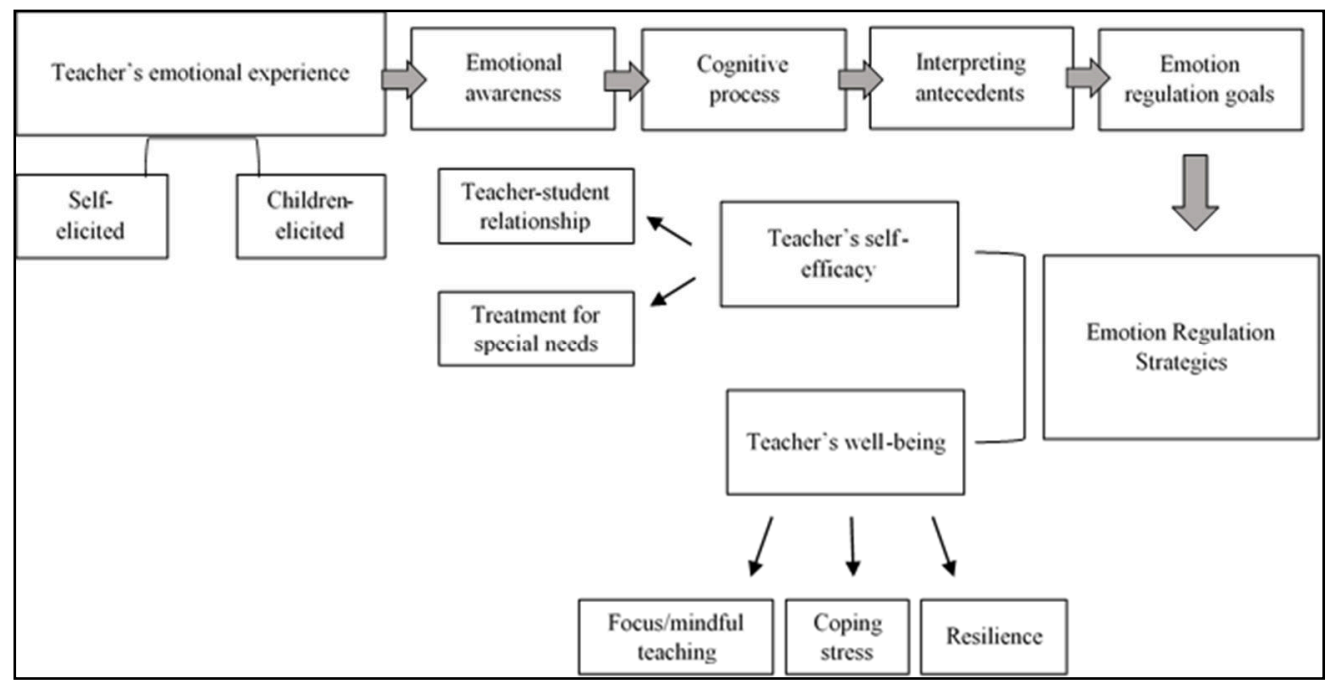

Fig. 2. Empirical Model of Teacher's Emotion Regulation and Well-being

\section{Conclusion}

This study sheds light into a deeper understanding about the process and impact sustainability of teacher's emotion regulation. Its validates the findings from previous study by Sutton, Sutton, et.al, and Hosotani \& Imai Matsumura [1], [10], [11]. Begin with exploring emotional experiences which developed awareness and leads to the implementation of emotion regulation strategies. The teacher's statement convey the benefits of implementing emotion regulations while dealing with special need students. Teachers believe that emotion regulation is significant to maintain the order of their daily teaching activities with students. Moreover, teachers are aware about the positive impact on their feeling after they implement emotion regulation strategies. Emotion regulation improves teacher's efficacy to conduct treatment for special needs student as well as nurturing a better teacher-student relationship.

Furthermore, findings on how emotion regulation resulted in a sense of well-being are remarkable. This findings distinct this study from the previous, as shown in the difference between the conceptual model in Figure 1 and the empirical model in Figure 2. This study provides evidence on how emotion regulation plays significant role in creating positive emotions, and create the sense of well-being. Emotions defines the life of human, and it lives in every human experiences. Emotions become an inseparable part of human existence. Every human beings in their existence, ineluctably, want purpose and meaning in life. According to Seligman, a meaningful life is a state of well-being, a complex psychological construct, comprised by several elements including positive emotions, engagement, meaning, positive relationship, and accomplishment [16]. Well-being is everyone's goal, consciously or unconsciously, people will seek for its elements in everyday life. As for positive emotions, people need it more in order to survive the unpredictable challenges at work, relationship, and 
other life courses. Teachers statement about the feeling of gratitude, patience (sabr), genuine (ikhlas), and blessed describes the state of spiritual well-being, a mental state and belief that there is a power which bigger than self. People engaging on a transcendental belief will need less effort to present positive emotions, feeling of peace and satisfaction that is a state of spiritual well-being and living in a relationship with God. Enjoying the sense of spiritual wellbeing result in enhancing resilience, becoming protective factor to prevent potential mental health problems [21].

Despite the valuable findings, this study has some limitations. The target of the study should be differ more in characteristics, targeting teachers from different inclusive schools, namely from private and state inclusive schools. Teacher's experience from various backgrounds will enrich and highlight the uniqueness of the qualitative data. Although this study shows the benefit of using preventative and responsive emotion regulation strategies, the evidence about which strategy is the most effective still need further examination. Further research may focus on the effectiveness of emotion regulation strategies, an experimental or a mixed-method study is strongly suggested.

Pragmatically speaking, this research may provide an important basis to rule out some program designed to help teachers improving their emotional competencies. Emotion regulation is an important skill to master and a golden ticket to attain emotional intelligence [1], improve well-being and avoid mental health risk [3]. The evidences from this study will be helpful to develop a systematic emotional/psychological skill training program for teachers in inclusive school.

\section{Acknowledgments}

This research was facilitate by grant from the State Higher Education Operational Aid (BOPTN) year 2020 managed by the Center of Research and Community Service (LP2M) Walisongo State Islamic University of Semarang. We would also like to acknowledge all of the research participants and reviewers.

\section{References}

[1] R. Hosotani and K. Imai-matsumura, "Emotional experience , expression , and regulation of high-quality Japanese elementary school teachers," Teaching and Teacher Education, vol. 27, no. 6, pp. 1039-1048, (2011).

[2] L. Zhang, S. Yu, and L. Jiang, "Chinese preschool teachers ' emotional labor and regulation strategies," Teaching and Teacher Education, vol. 92, pp. 1-10, (2020).

[3] P. D. MacIntyre, J. Ross, K. Talbot, S. Mercer, T. Gregersen, and C. A. Banga, "Stressors, personality and wellbeing among language teachers," System, vol. 82, pp. 26-38, (2019).

[4] P. A. Jennings, S. Doyle, Y. Oh, D. Rasheed, J. L. Frank, and J. L. Brown, "Long-term impacts of the CARE program on teachers' self-reported social and emotional competence and well-being," Journal of School Psychology, vol. 76, no. October 2018, pp. 186-202, (2019).

[5] R. W. Taylor and R. P. Ringlaben, "Impacting Pre-service Teachers' Attitudes toward Inclusion," Higher Education Studies, vol. 2, no. 3, pp. 16-23, (2012).

[6] U. Muzayanah, "Penyelenggaraan pendidikan inklusif pada Madrasah Ibtidaiyah (MI) Keji Ungaran Jawa Tengah," Penamas Jurnal Keagamaan dan Kemasyarakatan, vol. 
29, no. 2, pp. 221-226, (2016).

[7] R. M. Sholikhah, "Pendidikan Inklusif Di Kementerian Agama. (Studi Di Madrasah Ibtidaiyah Ma'arif Giriloyo 2 Dan Madrasah Ibtidaiyah Yappi Balong)," UIN Sunan Kalijaga Yogyakarta, (2016).

[8] W. S. S. Pandia and M. Purwanti, "Teachers' perceptions of school climate in inclusive schools," Psikohumaniora Jurnal Penelitian Psikologi, vol. 4, no. 1, p. 27, Apr. (2019).

[9] A. Oktradiksa, "Analisis Persepsi Guru Madrasah Tentang Konsep Sekolah Inklusi Di Mi Muhammadiyah Jagalan Kabupaten Magelang," JPK Jurnal Pendidian Khusus, vol. 13 , no. 2, pp. 77-95, (2016).

[10] R. E. Sutton, R. Mudrey-camino, C. C. Knight, and R. E. Sutton, Teacher's Emotion Regulation and Clasroom Management. Theory Into Practice, no. November 2014, pp. 37-41, (2009).

[11] R. E. Sutton, "Emotional regulation goals and strategies of teachers," Social Psychology of Education, vol. 7, pp. 379-398, (2004).

[12] J. Bielak and A. Mystkowska-wiertelak, "Language teachers ' interpersonal learnerdirected emotion-regulation strategies," Language Teaching Research, pp. 1-24, (2020).

[13] S. LeBlanc, B. Uzun, A. Aydemir, and C. Mohiyeddini, "Validation of an Emotion Regulation Training Program on Mental Well-Being," Psychol. Rep., vol. 123, no. 5, pp. 1518-1536, (2020).

[14] I. Izzaturrohmah and N. M. Khaerani, "Peningkatan Resiliensi Perempuan Korban Pelecehan Seksual Melalui Pelatihan Regulasi Emosi," Psikohumaniora Jurnal Penelitian Psikologi, vol. 3, no. 1, p. 117, Aug. (2018).

[15] J. J. Gross and O. P. John, "Individual Differences in Two Emotion Regulation Processes: Implications for Affect, Relationships, and Well-Being," Journal of Personality and Social Psychology, vol. 85, no. 2, pp. 348-362, (2003).

[16] M. E. P. Seligman, Flourish: A Visionary New Understanding of Happiness and Wellbeing. Australia: Random House, (2012).

[17] J. J. Gross, "The emerging field of emotion regulation: An integrative review," Review of General Psychology, vol. 2, no. 3, pp. 271-299, (1998).

[18] Y. F. La Kahija, Penelitian Fenomenologis Jalan Memahami Pengalaman Hidup. Yogyakarta: PT Kanisius, (2017).

[19] M. Smith, J. A., Flowers, P., \& Larkin, Interpretative phenomenological analysis. Theory, method and research. London: Sage, (2009).

[20] V. Eatough and J. Smith, "'I was like a wild wild person': Understanding feelings of anger using interpretative phenomenological analysis," British Journal of Psychology, vol. 97, no. 4, pp. 483-498, (2006).

[21] L. Smith, R. Webber, and J. DeFrain, "Spiritual well-being and its relationship to resilience in young people: A mixed methods case study," SAGE Open, vol. 3, no. 2, pp. 1-16, (2013). 